\title{
Par Pond Vegetation Status 1996
}

by

H. E. Mackey

Westinghouse Savannah River Company

Savannah River Site

Aiken, South Carolina 29808

R. S. Riley

DISTRIBUTION OF THIS DOCUMENT IS UNLIMITED

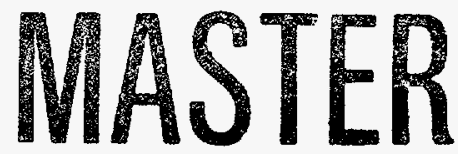

DOE Contract No. DE-AC09-89SR18035

This paper was prepared in connection with work done under the above contract number with the U. S.

Department of Energy. By acceptance of this paper, the publisher and/or recipient acknowledges the U. S. Government's right to retain a nonexclusive, royalty-free license in and to any copyright covering this paper, along with the right to reproduce and to authorize others to reproduce all or part of the copyrighted paper. 


\section{DISCLAMMER}

Portions of this document may be illegible in electronic image products. Images are produced from the best available original document. 


\section{DISCLAMMER}

This report was prepared as an account of work sponsored by an agency of the United States Government. Neither the United States Government nor any agency thereof, nor any of their employees, makes any warranty, express or implied, or assumes any legal liability or responsibility for the accuracy, completeness, or usefulness of any information, apparatus, product, or process disclosed, or represents that its use would not infringe privately owned rights. Reference herein to any specific commercial product, process, or service by trade name, trademark, manufacturer, or otherwise does not necessarily constitute or imply its endorsement, recommendation, or favoring by the United States Government or any agency thereof.: The views and opinions of authors expressed herein do not necessarily state or reflect those of the United States Govemment or any agency thereof.

This report has been reproduced directly from the best available copy.

Available to DOE and DOE contractors from the Office of Scientific and Technical Information, P.O. Box 62, Oak Ridge, TN 37831; prices available from (615) 576-8401.

Available to the public from the National Technical-Information Service, U.S. Department of Commerce, 5285 Port Royal Road, Springfield, VA 22161. 
WSRC-RP-96- 6603

\title{
PAR POND VEGETATION STATUS 1996
}

\author{
by
}

Halkard E. Mackey, Jr. and R. S. Riley Westinghouse Savannah River Company

Savannah River Technology Center

Environmental Sciences Section

Aiken, SC 29808

December 1996

This information contained in this report was developed during the course of work under Contract No. DE-AC09-89SR18035 with the US Department of Energy.

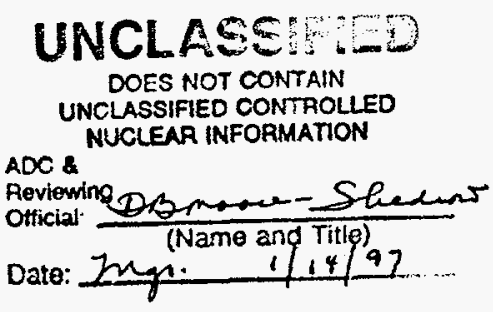




\title{
PAR POND VEGETATION STATUS 1996
}

\author{
by \\ Halkard E. Mackey, Jr. and R. S. Riley \\ Westinghouse Savannah River Company \\ Savannah River Technology Center \\ Environmental Sciences Section \\ Aiken, SC 29808
}

\begin{abstract}
A survey of the newly emergent, shoreline aquatic plant communities of Par Pond began in June 1995, three months after the refilling of Par Pond to approximately 200 feet above mean sea level. These surveys continued in July, September, and late October, 1995, and into the early spring and late summer of 1996. Communities similar to the pre-draw down, Par Pond aquatic plant communities continue to become re-established. Emergent beds of maidencane, lotus, waterlily, watershield, and Pontederia are extensive and well developed. Measures of percent cover, width of beds, and estimates of area of coverage with satellite data indicate regrowth within two years of from 40 to 60 percent of levels prior to the draw down. Cattail occurrence continued to increase during the summer of 1996, especially in the former warm arm of Par Pond, but large beds common to Par Pond prior to the draw down still have not formed. Lotus has invaded and occupies many of the areas formerly dominated by cattail beds. To track the continued development of macrophytes in Par Pond, future surveys through the summer and early fall of 1997 , along with the evaluation of satellite data to map the extent of the macrophyte beds of Par Pond, are planned.
\end{abstract}

\section{INTRODUCTION}

Par Pond, a 1012-ha, cooling-water reservoir on the Savannah River Site (SRS), was created in 1958 by constructing an earthen dam on the upper reaches of the Lower Three Runs Creek drainage system (Wilde and Tilly, 1985). Par Pond served as a re-circulating, cooling-water reservoir for $R$ Reactor until 1963 and for $P$ Reactor from 1961 until 1988. P Reactor operated approximately $70 \%$ of the time prior to 1988. During the summer months, the temperatures near the bubble-up (warm arm) in Par Pond ranged from 22 to 42 degrees C (Jones et al., 1979). Maximum shoreline water temperatures in the vicinity of the bubble-up ranged from 32 to 35 degrees $C$ (Liu et al., 1978). The thermal effluent cooled rapidly as it dispersed primarily through the southern half of the reservoir (Ezra and Tinney, 1985). The north and west arms of Par Pond had temperatures at or only slightly above typical lake temperatures for the region (Liu et al. , 1978). 
The water level of Par Pond remained relatively stable, fluctuating typically less than $0.15 \mathrm{~m}$ in most years. Natural invasion of aquatic vegetation occurred over the 33year history of the lake, until mid-1991, when Par Pond was lowered from 200-ft above mean sea level (MSL) to 181-ft above MSL in about a two month period. Prior to lowering in 1991, Par Pond was bordered by extensive beds of persistent and nonpersistent aquatic macrophytes. These beds often exceeded $20-40 \mathrm{~m}$ in width and in several areas exceeded 100m. For example, from 1988, 1989, and 1990 SPOT satellite data, it was estimated that there were along the shore line of Par Pond, 192 ha of cattails or persistent emergent macrophytes present during the 1988 growing season, 179 ha in 1989, and 175 ha in 1990; and that there were 150 ha of waterlilies or other non-persistent macrophytes in 1988, 126 ha in 1989, and 149 ha in 1990 (Jensen et al., 1993; Narumalani, 1993). Earlier studies by Ezra and Tinney (1985) from airborne multispectral scanner data collected from the fall of 1985 had estimated that there were approximately 266 ha of emergent macrophytes along the Par Pond shoreline.

In 1987, transects were established along the shoreline of Par Pond (Jensen et al., 1991, 1992, 1993; Jensen and Mackey, 1991; Narumalani, 1993). The dominate aquatic macrophyte patterns were recorded each spring (April or May) and fall (September or October) from 1988 through June 1991, just prior to the lowering of the Par Pond water level. In these previous studies, the major species present in both the persistent (emergent, i.e., cattails) and non-persistent (floating-leafed, i.e., waterlily, lotus) macrophyte categories were recorded, along with the width of each bed along the transects and estimates of percent cover by species at each transect. SPOT satellite data were also collected and analyzed for the spring and fall for this same time period (1988-1990) to provide estimates of area of coverage by major aquatic macrophyte category for the lake. These methods and data are summarized in the references above.

Baseline, vertical, 9 by 9 inch format, aerial, false color infrared photography was taken on April 25, 1995, at 10,000 foot altitude during a spring time over flight of Par Pond. This photography was used as a general reference during the Par Pond surveys, even though little emergent vegetation is noticeable in the photography, except in a few isolated coves or inlets of the lake. Similar aerial photography of Par Pond was again acquired on April 17, 1996, and this photography shows initial emergence of floating-leaf macrophyte beds.

Beginning in June, 1991, Par Pond was lowered from $200 \mathrm{ft}$ above MSL to 181 $\mathrm{ft}$ above MSL. This lowering was sufficient to expose both the emergent and nonemergent macrophyte beds of the Par Pond shoreline to drying conditions. Therefore, extensive macrophyte losses occurred. Initial surveys in August 1992 indicated some re-invasion on the newly exposed shoreline. Plant succession was occurring on about $65 \%$ of the exposed lake bed (newly exposed shoreline) with approximately $35 \%$ still barren. Grasses, sedges and rushes were the dominant forms with a mixture of old-field species including dog-fennel and loblolly pine invasion, which became more evident after the spring of 1993 (Narumalani, 1993). In isolated pockets within coves of Par Pond, sufficient ground water seepage or inflow from small streams allowed survival of remnants of the Par Pond macrophyte communities, as evident in late April 1995 vertical aerial photography (i.e., beds of water lilies in the cove south of the Par Pond pump house). In mid-October 1994, Par Pond began to refill and by mid-March 1995 Par Pond water levels approached the level of the former full pool (Figure 1). - The Par Pond water level has remained relatively constant since refill, fluctuating only about 0.6 foot $(0.2 \mathrm{~m})$ in 1995 following completion of refill (Figure 2) and about 1.15 foot $(0.35 \mathrm{~m})$ from January through mid-November, 1996 (Figure 3). 
REFILLING OF PAR POND

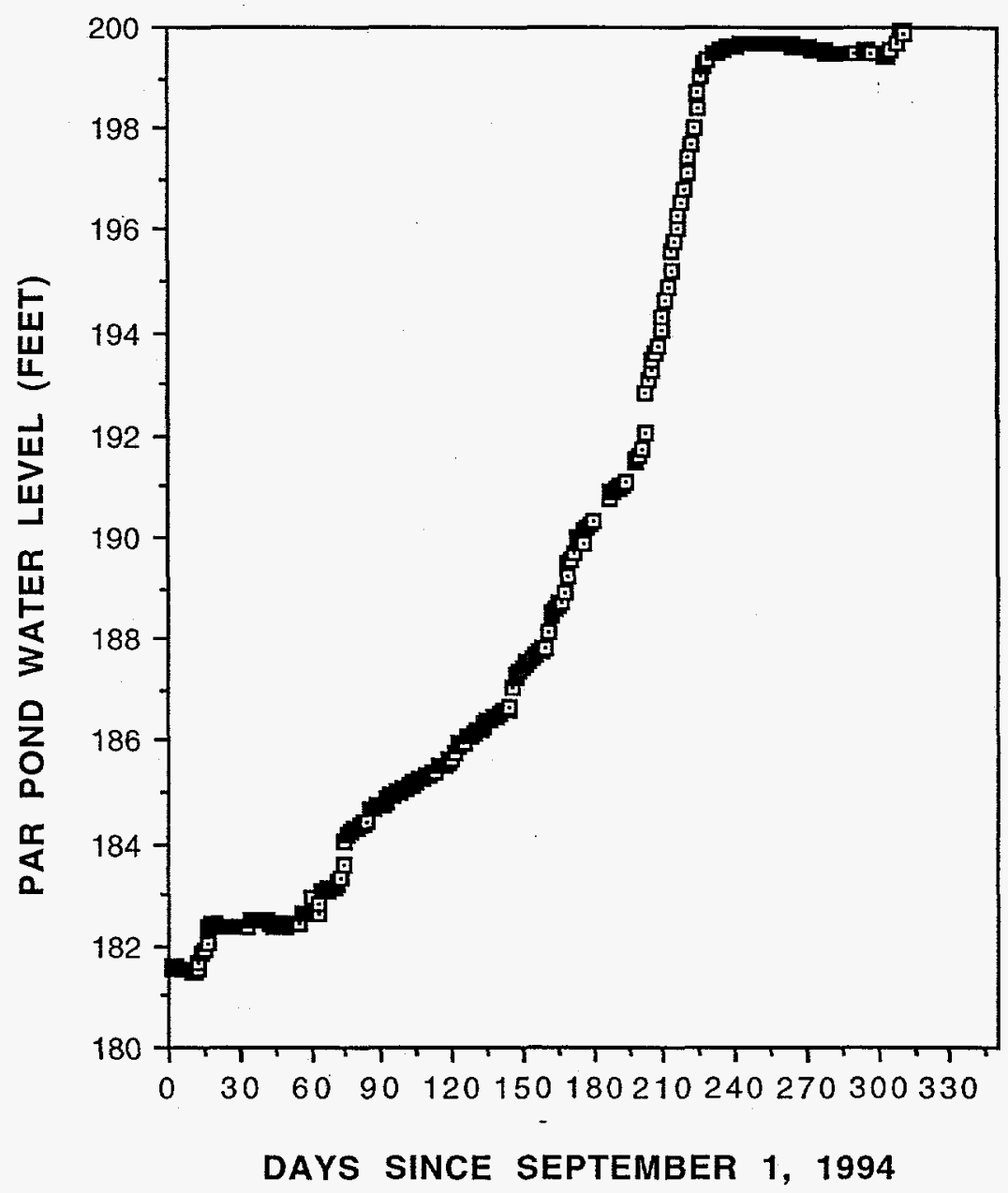

Figure 1. Refilling of Par Pond During the Winter and Early Spring of 1995 


\section{PAR POND WATER LEVEL CHANGES AND MACROPHYTE SAMPLING DATES}

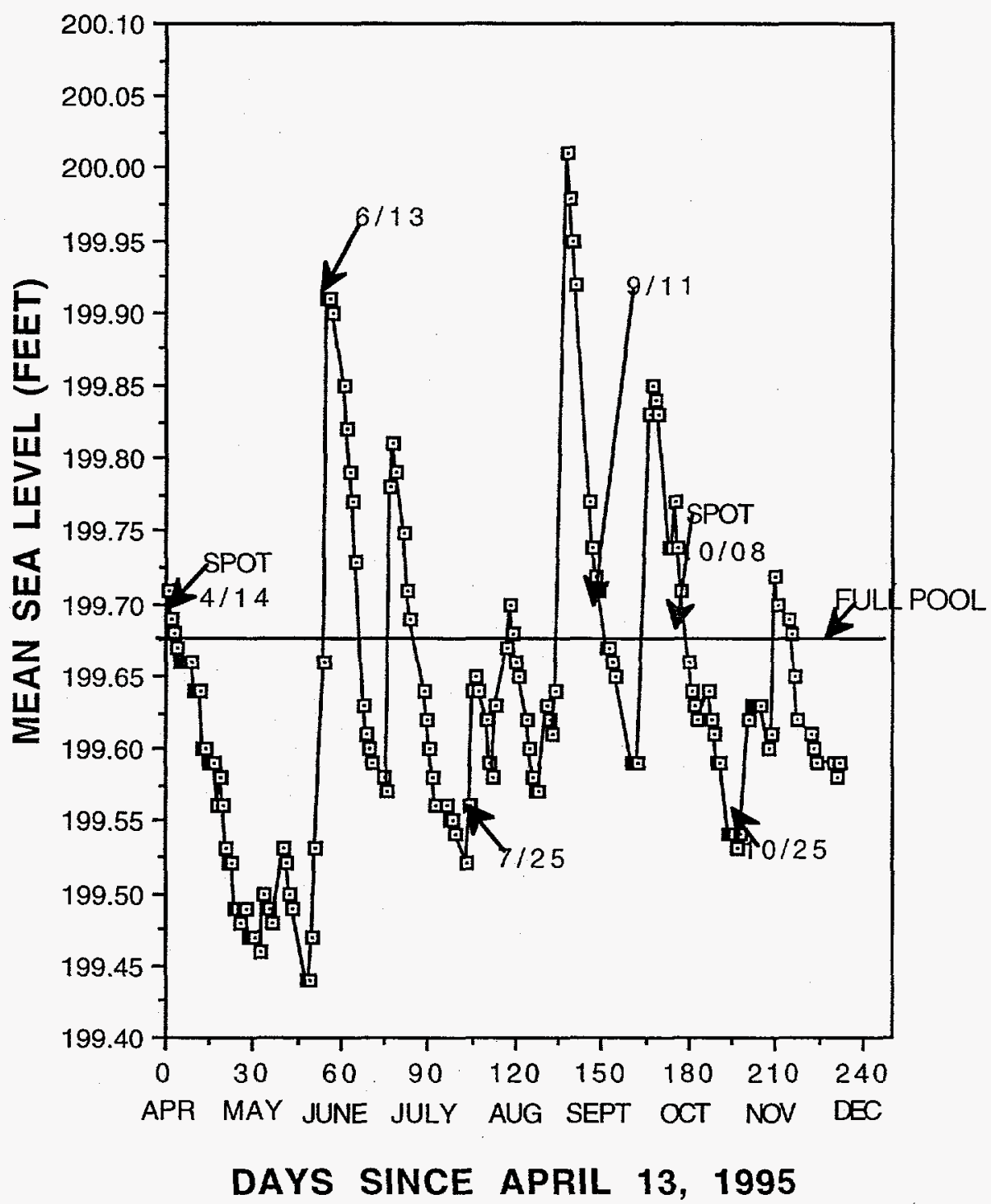

Figure 2. Water Level Changes Following Refill of Par Pond, 1995. Dates of SPOT Satellite Data Collection and Macrophyte Surveys Are Indicated. 


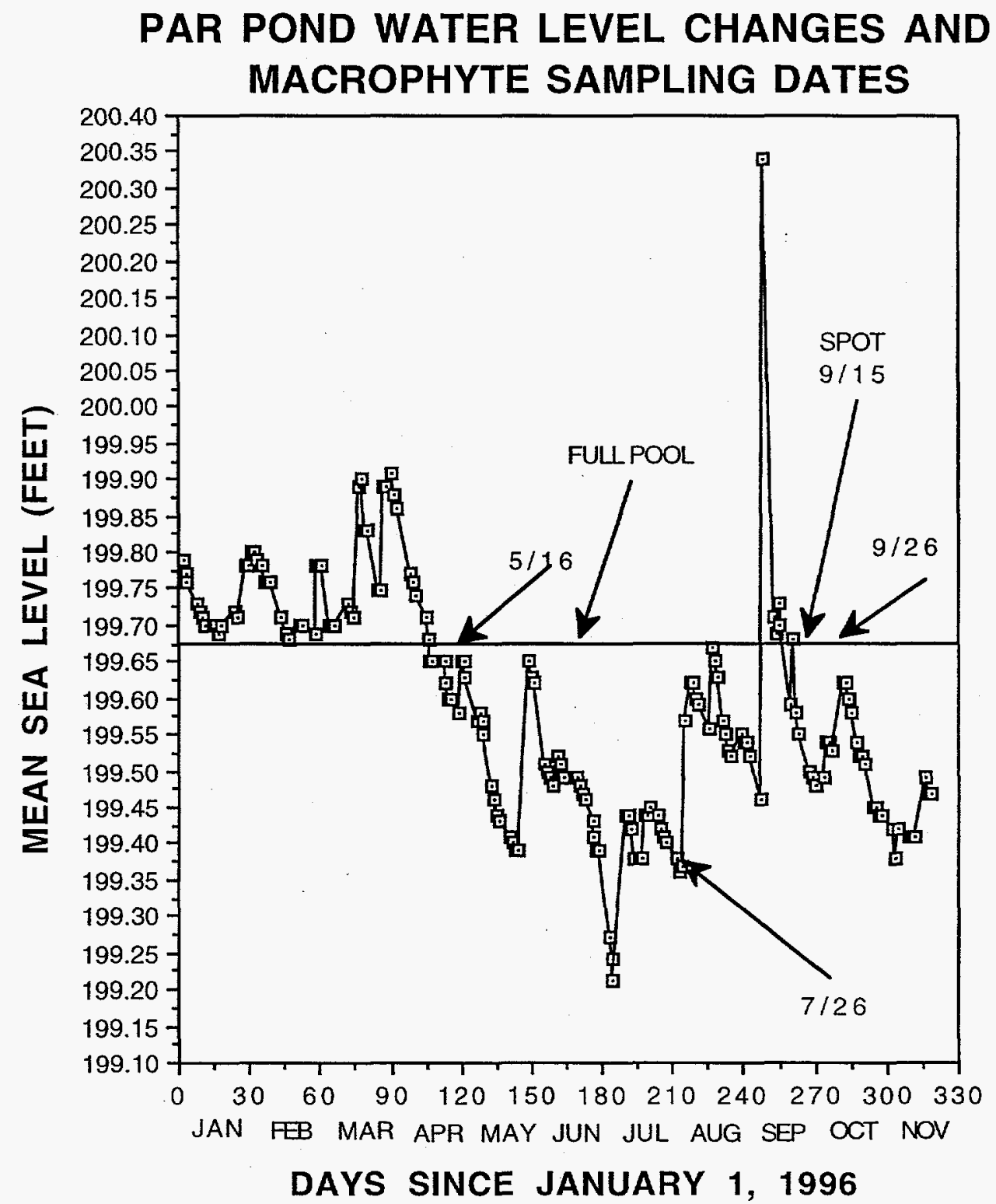

Figure 3. Water Level Changes in Par Pond January through November, 1996. Dates of Macrophyte Surveys Are Indicated. 
Of the transects along the Par Pond shoreline established for the 1988 through June, 1991, surveys, forty-eight (48) were relocated on March 14, 1995. Descriptive notes on the vegetation patterns at each transect were taken beginning on June 13-14, 1995, to indicate the condition of any standing vegetation following refill and initial regrowth of macrophyte communities. Photographic records of each transect were taken on June 15, 1995. The transects were revisited on July 25-26, 1995, and photographed on July 25 and 27, 1995. They were surveyed again on September 11 and 12 and the transects were photographed on September 15, 1995. A final survey in 1995 was conducted on October 25, 1995, and photography was taken on October 27 , 1995. Species present was recorded along with a nominal estimate of percentage cover for any species appearing to occupy more than a "trace" $(<0.1 \%)$ of the water surface (Phillips, 1959, Mueller-Dombois and Ellenberg, 1974). Two zones (an inner and an outer zone) were characterized at each transect on each of the four surveys. Both zones started at the location pole of the transect marker which was used previously in the 1988-1991 surveys to mark the boundary between the persistent emergent aquatic beds (i.e. primarily cattails, spike rush) and the non-persistent, floating-leafed macrophytes beds (i.e. waterlilies and lotus). Water depth at the transect marker averaged approximately 1 meter in previous surveys (Jensen et al., 1991a, 1991b, 1992, and 1993; Jensen and Mackey, 1991; Narumalani, 1993). All transect pole locations were located to approximately one meter accuracy $(x, y)$ with Global Position Survey (GPS) equipment for future reference.

In 1996, surveys were again conducted at the locations of the 48 transects. Data on species presence and estimates of percentage coverage and width of the macrophyte beds for the outer transects were taken on May 16 and 20,1996, and on July 26, 29, 31, August 1, 1996, and on September 25 and 26, 1996, as described above. Photography was taken of each transect on January 15, April 8, May 22, August 5, and September 25, 1996. The results of the surveys from the spring and summer of 1996 are summarized in Table 1 below. SPOT satellite data of SRS were acquired on September 15, 1996 (Figure 3 above).

\section{RESULTS}

Since the refilling of Par Pond, most of the old field species (i.e., dog fennel, broom sedge, poke berry, briars) which had occupied much of the exposed shoreline are now absent. Loblolly pine were observed in both the outer and inner zones at the transacts and except for shallow areas along the shoreline has died. The most common shrubs and hardwood tree species along Par Pond were newly invaded willow (Salix spp.) and red maple (Acer rubrum), but even these more flood tolerant species are showing indications of stress and/or a few have died from the continued flooding over the past two years. Red maple and willow continue to be the most common hardwood along the shallow shoreline in 1996.

The shoreline aquatic vegetation of Par Pond is continuing to undergo rapid redevelopment in 1996. Table 1 summarizes percentage occurrence and coverage estimates for the most common species observed at the transects during the surveys from the summer of 1996. Figures 4 and 5 show the changes in relative importance (percent occurrence plus percent cover) in these macrophytes during the 1995 and 1996 growing period. Maidencane, one of the current dominant species along the shallow shoreline of Par Pond continued to show a slight decline in both the inner and outer transects (Table 1 and Figures 3 and 4). Other major dominant species which occurred in Par Pond prior to the draw down continue to increase, especially lotus and waterlily (both in the inner and outer transects), and spike rush and cattails (inner transects 
primarily). Gattails are present, both in widely scattered beds along the shallow shoreline, and also as long linear narrow beds primarily in the former warm arm of Par Pond. However, most areas formerly occupied by cattails prior to the draw down are dominated now by lotus, waterlily, and watershield. Lotus has expanded more than any other surface macrophyte into the former areas occupied by cattails. Pontederia has remained as a common dominant species in the shallow water transect area, especially in the northern portions of the lake.

Figure 6 represents a comparison between transects from 1988 and 1990 and the regrowth that is taking place in 1995 and 1996. The average percent cover for the 48 transects (outer zones only) was between 65-70 percent for July 1989 and September 1990; whereas in September 1995, the average percent cover for these same transects for the outer zone was approximately 45 percent and for 1996 in late July was 58 percent and 64 percent in late September. For comparison purposes the emergent macrophyte planted zones of L Lake in 1989 had an average percent cover of 40 percent two years after initial planting had taken place in 1987 (Kroeger, 1990). For all of the 48 outer transects in summer of 1988, 1989, and 1990, the average width was 49,44 , and 28 meters respectively. The average width for all of the 48 outer transects in 1995 was about 18 meters in September and October; and averaged 23 meters in May 1996; 28 meters in late July 1996; and averaged 37 meters in late September 1996. (Note: No measurements of vegetation growth were made at any of the transect locations during the period of draw down.)

From 1988, 1989, and 1990 SPOT satellite data, it was estimated that there were along the shoreline of Par Pond, 192 ha of cattails or persistent emergent macrophytes present during the 1988 growing season, 179 ha in 1989, and 175 ha in 1990; and that there were 150 ha of waterlilies or other non-persistent macrophytes in 1988, 126 ha in 1989, and 149 ha in 1990 (Jensen et al., 1993; Narumalani, 1993). Earlier studies by Ezra and Tinney (1985) from airborne multispectral scanner data collected from the fall of 1985 had estimated that there were approximately 266 ha of emergent macrophytes along the Par Pond shoreline. Using similar methods for spring and fall SPOT XS (multispectral scanner data) from 1995 and fall SPOT XS data from late summer 1996, it was estimated that there were approximately 120 hectares of macrophytes along the shoreline of Par.Pond in late 1995 and 170 hectares in September 1996. These estimates with satellite data for total macrophyte coverage along the Par Pond shoreline for 1995 and 1996 are approximately 30 to 50 percent of total estimates for 1985 and 1988 through 1990. 
Table 1. Summary of Species Observed at the Par Pond Transects, June, July, and September, 1996

\begin{tabular}{|c|c|c|c|c|c|c|c|c|}
\hline Species & $\begin{array}{c}\text { Inner } \\
\text { Jun }\end{array}$ & Zones & $\begin{array}{l}\text { Outer } \\
\text { June }\end{array}$ & Zones & $\begin{array}{r}\text { Inner } \\
\text { Jul }\end{array}$ & Zones & $\begin{array}{l}\text { Outer } \\
\text { July }\end{array}$ & Zones \\
\hline & $\% \mathrm{O}$ & $\% \mathrm{C}$ & $\%$ & $\% \mathrm{C}$ & $\% \mathrm{O}$ & $\% \mathrm{C}$ & $\%$ & $\% \mathrm{C}$ \\
\hline $\begin{array}{l}\text { Maidencane } \\
\text { (Panicum hemitomon) }\end{array}$ & 68.8 & 15.3 & 45.8 & 10.6 & 60.7 & 16.6 & 52.1 & 7.8 \\
\hline Lotus (Nelumbo lutea) & 72.9 & 6.9 & 85.4 & 6.4 & 89.6 & 17.2 & 93.8 & 24.6 \\
\hline $\begin{array}{l}\text { Watershield } \\
\text { (Brasenia schreberi) }\end{array}$ & 27.1 & 2.5 & 37.2 & 5.1 & 27.1 & 4.0 & 45.8 & 8.8 \\
\hline $\begin{array}{l}\text { Water Lily } \\
\text { (Nymphaea ordorata) }\end{array}$ & 70.8 & 19.1 & 60.4 & 12.2 & 68.8 & 18.6 & 58.3 & 16.1 \\
\hline $\begin{array}{l}\text { Penny Wort } \\
\text { (Hydrocotyle sp.) }\end{array}$ & 4.2 & 0.02 & 2.1 & 0.2 & 8.3 & 0.1 & 2.1 & 0.1 \\
\hline $\begin{array}{l}\text { Spike Rush } \\
\text { (Eleocharis sp.) }\end{array}$ & 18.8 & 0.5 & 2.1 & 0.2 & 20.8 & 0.9 & 4.2 & 0.3 \\
\hline Rushes (Juncus sp.) & 29.2 & 1.4 & $\cdots$ & $\cdots$ & 22.9 & 0.8 & $\cdots$ & $\ldots$ \\
\hline $\begin{array}{l}\text { Pickerel Weed } \\
\text { (Pontederia cordata) }\end{array}$ & 27.1 & 6.2 & 2.1 & 0.1 & 27.1 & 6.3 & 2.1 & 0.4 \\
\hline Cattails (Typha spp.) & 27.1 & 0.6 & 4.2 & 0.004 & 31.2 & 0.5 & 4.2 & 0.02 \\
\hline $\begin{array}{l}\text { Creeping Burhead } \\
\text { (Echinodorus sp.) }\end{array}$ & 4.2 & 0.04 & $\cdots$ & $-\cdots$ & 4.2 & 0.02 & $\cdots$ & $\cdots$ \\
\hline $\begin{array}{l}\text { Giant Cutgrass } \\
\text { (Zizaniopsis sp.) }\end{array}$ & 4.2 & 0.004 & $\cdots$ & $\ldots$ & 14.6 & 0.3 & $\cdots$ & $\cdots$ \\
\hline
\end{tabular}


Table 1. Continued--Summary of Species Observed at the Par Pond Transects, June, July, and September, 1996

Species

$\begin{array}{cc}\text { Inner Zones } & \text { Outer Zones } \\ \text { Sept } & \text { Sept } \\ \% \mathrm{O} \% \mathrm{C} & \% \mathrm{O} \% \mathrm{C}\end{array}$

Maidencane

(Panicum hemitomon)

$\begin{array}{llll}64.6 & 15.8 & 45.8 & 3.4\end{array}$

Lotus (Nelumbo lutea)

$\begin{array}{llll}87.5 & 21.9 & 93.8 & 36.7\end{array}$

Watershield

$\begin{array}{llll}31.2 & 5.0 & 45.8 & 11.9\end{array}$

(Brasenia schreberi)

Water Lily

$\begin{array}{llll}66.7 & 15.1 & 58.3 & 11.8\end{array}$

(Nymphaea ordorata)

Penny Wort

(Hydrocotyle sp.)

$\begin{array}{llll}8.3 & 0.1 & 2.1 & 0.2\end{array}$

Spike Rush

(Eleocharis sp.)

$\begin{array}{llll}27.1 & 2.5 & 4.2 & 0.4\end{array}$

Rushes (Juncus sp.)

$25.6 \quad 1.0$

Pickerel Weed

$\begin{array}{llll}25.0 & 6.5 & 2.1 & 0.1\end{array}$

(Pontederia cordata)

Cattails (Typha spp.)

$\begin{array}{llll}31.2 & 0.8 & 4.2 & 0.02\end{array}$

Creeping Burhead

(Echinodorus sp.)

$2.1 \quad 0.02 \quad \cdots \cdots$

Giant Cutgrass

$33.3 \quad 0.3$

(Zizaniopsis sp.)

$\% \mathrm{O}=$ percent occurrence,$\quad \% \mathrm{C}=$ percent cover 


\section{MACROPHYTES INNER TRANSECTS}

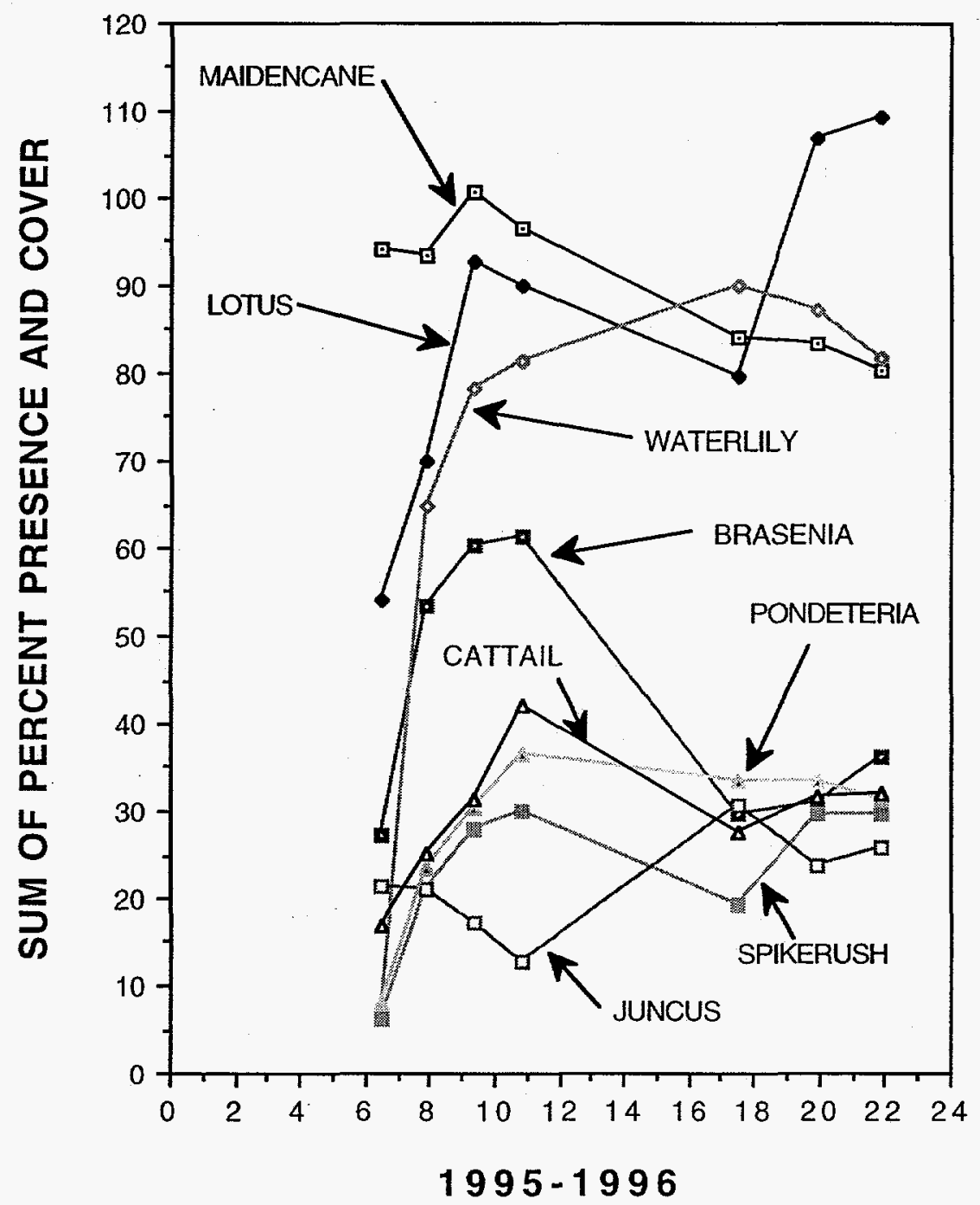

Figure 4. Trends in Macrophyte Growth in the Inner Transects of Par Pond in 1995 and 1996 


\section{MACROPHYTES OUTER TRANSECTS}

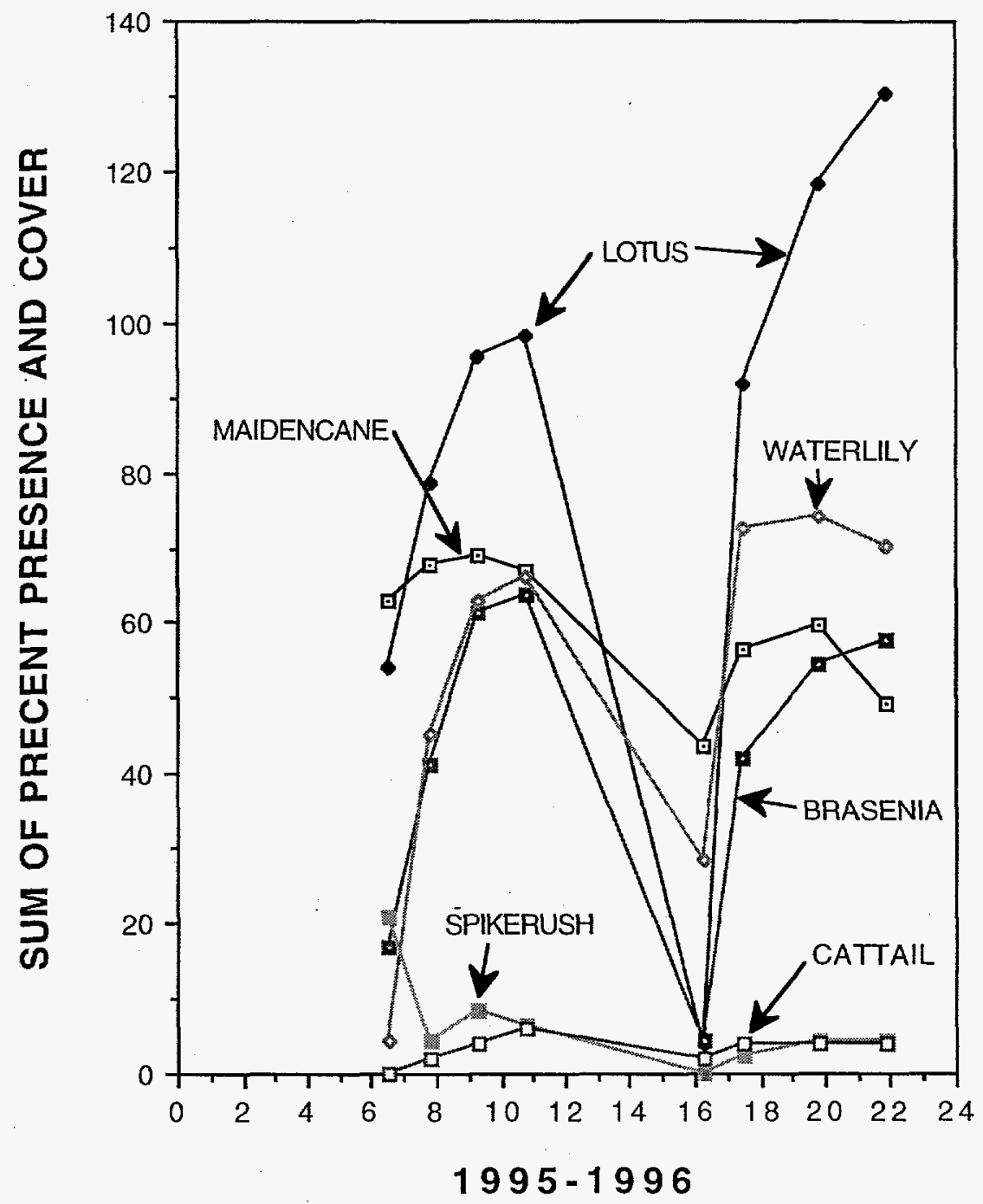

Figure 5. Trends in Macrophyte Growth in the Outer Transects of Par Pond in. 1995-1996 


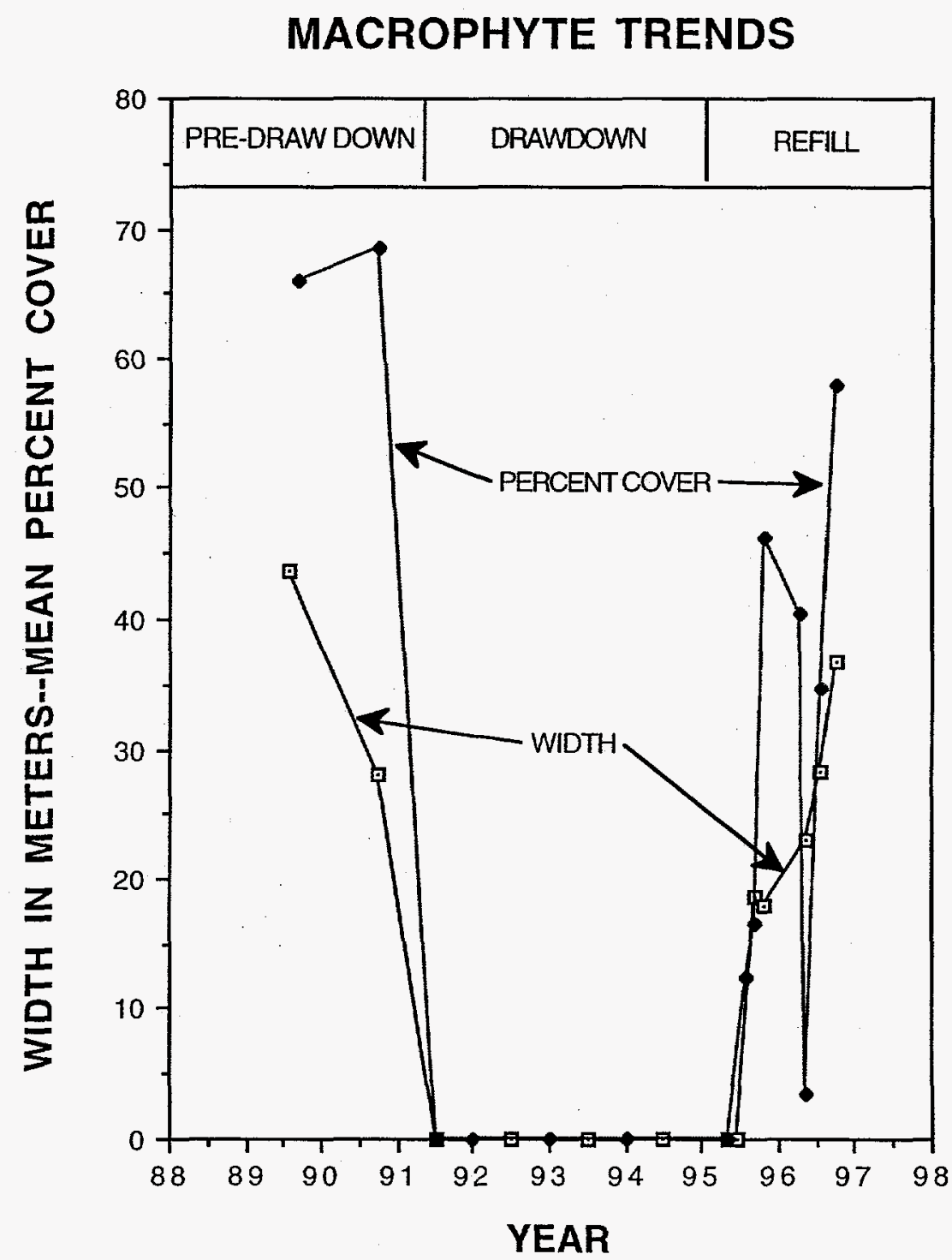

Figure 6. Comparisons of Par Pond Macrophytes Pre-Draw Down with 1995-1996 Regrowth. (Note: No measurements were taken at the transect locations during the draw down period.) 


\section{DISCUSSION AND CONCLUSIONS}

The shoreline aquatic vegetation of Par Pond is continuing to undergo rapid redevelopment. Measures of percent cover, width of beds, and estimates of the areas of regrowth from in situ and satellite data, all indicate recovery estimates in the 40 to 60 percent range after the end of two growing seasons following refill of Par Pond to a normal pool level of approximately 200 feet above mean sea level.

Maidencane, the current dominant along the inner shallow water shoreline of Par Pond remained about the same from the 1995 to 1996 surveys. The maidencane in the deeper water outer transect areas continues to decline from 1995 to 1996 . Other major dominant species which occurred in Par Pond prior to the draw down continue to increase, especially lotus, waterlily, and watershield in the outer transects, and lotus and spike rush in the inner transects. Cattails are present, with widely scattered beds throughout much of the lake and longer linear beds forming in the former warm middle arm of Par Pond. Most areas formerly occupied by cattails prior to the draw down continue to be dominated by maidencane and/or Pontederia along the shallow water shoreline. Lotus has expanded in 1996 to occupy many areas formerly dominated by cattails. The water level in Par Pond for the first two years following refill has fluctuated typically less than one foot. The woody species, such as loblolly pine, red maple, and willow, are declining as expected following the refill of Par Pond; however, a well developed hardwood band of willow and red maple exist around the margins of the lake. These early surveys are already providing good evidence of the likely direction that the Par Pond communities will take in their development.

The exact nature of the final community types are speculative at this point. The water chemistry of Par Pond is likely to be more similar to Pond $B$ than it was during past P-Reactor operations, thus lotus and Brasenia are likely to become more common with less cattail development than in the past.

Also the water level of Par Pond may be allowed to fluctuate naturally as much as 1 to 2 meters. Plants inhabiting irregularly water levels are subject to a wide range of environmental conditions ranging from near drought to total inundation. Although many wetlands species can survive fluctuating hydrologic regimes, species tolerances to the hydrologic extremes will determine future community dominance patterns, as well as the timing of the fluctuations from year-to-year (Davis and Brinson, 1980; Merendino and Smith, 1991; Millar, 1973).

Documentation of the relative performances and adaptive strategies of dominant plant species under different hydrological regimes is necessary to develop predictive models of community patterns in freshwater bodies. For example, Kirkman and Sharitz (1993) on studies of maidencane (Panicum hemitomon) in Carolina bays on the SRS, noted that this species survived inundation to 1.18 meters via stem elongation and had percentage cover estimates as high as 30 percent in plots of this species in water depths to approximately 1.7 meters. Flower production was also observed in maidencane with flooding conditions in that same study (Kirkman and Sharitz,1993). Apparently the refilling of Par Pond during the spring of 1995 did not exceed the rates of stem growth and elongation following the emergence of maidencane in 1995 along much of the formerly exposed Par Pond shoreline. Kirkman and Sharitz (1993) postulate that increased dominance by maidencane occurs during periods of deep inundation during the 
growing season. Elongation of stems resulting from inundation during the growing season prior to deep winter water levels will enable this species to survive greater depths of flooding in winter. However, if the dead stems of maidencane are lost due wave action, or herbivore during the winter, then deep water areas of maidencane would not persist. Maidencane with its "head-start" and ability to tolerate more acid, lower nutrient water, its dense root system, and ability to adjust to changes in water level may prove to be a future dominant of the Par Pond shallow shoreline. However, wave action in deeper, more open water areas of Par Pond may inhibit continued survival and growth of maidencane, especially if the over wintering stem biomass is lost and subject to flooding (Kirkman and Sharitz, 1993). Relative drought tolerances infer that maidencane probably would become more prominent in the plant community during natural draw down or cycling of Par Pond lake levels (Kirkman and Sharitz, 1993).

Pontederia is well established and is likely to continue to exist along the edge of Par Pond in areas of water depth of less than 0.5 meters. Cattail beds are likely to continue to expand, probably through vegetative growth at the root systems. Spike rush is appearing in beds in areas almost identical to its occurrence in 1988-1990 surveys and studies. Lotus has expanded to the greatest extend in 1996 and should continue to remain a major dominant in both intermediate and deeper water areas up to depths of 2 to 3 meters. Lotus may likely replace, maidencane as it becomes more reduced in deeper water shoreline zones.

Members of the past macrophyte communities have become well established in all areas of Par Pond and are likely to survive slow variations in water level fluctuations given the high degree of recovery and regeneration following nearly four years of a continued 19-foot draw down in which much of the previous macrophyte beds died and seed banks were exposed.

Continued surveys though the summer and early fall of 1997, should provide good evidence of the likely direction that the Par Pond communities will take in their development.

\section{REFERENCES}

Davis, G. J. and M. M. Brinson. 1980. Responses of Submersed Vascular Plant Communities to Environmental Change. Report FWS/OBS-79/33, Office of Biological Services, Fish and Wildlife Service, Department of the Interior. 70pp.

Ezra, C. E. and L. R. Tinney. Par Pond Macrophyte Study Savannah River Plant, Aiken, South Carolina. EG\&G/EM Letter Report DOE (ONS-SRL)8513 (1985).

Jensen, J. R., S. Narumalani, O. Weatherbee, and H. E. Mackey. 1991. "Remote Sensing of Aquatic Macrophytes in a Southeastern Lake: Analysis of Vertical Aerial Photography and SPOT Digital Data. " Geo Info Systems. Winter, 1991

Jensen, J. R., S. Narumalani, O. Weatherbee, and H. E. Mackey, Jr. 1991. "Remote Sensing Offers an Alternative for Mapping Wetlands." Geo Info Systems. October, 1991. pp. 48-53. 
Jensen, J. R., S. Narumalani, O. Weatherbee, and H. E. Mackey, Jr. 1992. "Measurement of Seasonal and Yearly Macrophyte Changes in a Reservoir Using Multidate SPOT Panchromatic Data." Proceedings 1992 ASPRS-ACSM Annual Convention, Albuquerque, New Mexico, pp. 167-176.

Jensen, J. R., S. Narumalani, O. Weatherbee, K. S. Morris, Jr., and H. E. Mackey, Jr. 1992. "Predictive Modeling of Cattail and Waterlily Distribution in a South Carolina Reservoir Using GIS." Photogrammetric Engineering \& Remote Sensing. 58(11): $1561-1568$.

Jensen, J. R., S. Narumalani, O. Weatherbee, and H. E. Mackey, Jr. 1993.

"Measurement of Seasonal and Yearly Cattail and Waterlily Changes Using Multidate SPOT Panchromatic Data." Photogrammetric Engineering \& Remote Sensing. $9(4): 519-525$.

Jones, J. C., J. F. Hancock and E. H. Liu. 1979. "Biochemical and Morphological Effects of Temperature on Typha latifolia L. (Typhaceae) Originating from Different Ends of a Thermal Gradient. I. Controlled Environmental Studies". American Journal of Botany, $66(8): 902-906$.

Kirkman, L. K. and R. R. Sharitz. 1993. "Growth in Controlled Water Regimes of Three Grasses Common in Freshwater Wetlands of the Southeastern USA." Aquatic Botany. 44:345-359.

Kroeger, S. R. 1990. Wetland Vegetation Establishment in L-Lake. Report Number, SREL-39. Savannah River Ecology Laboratory, University of Georgia, Savannah River Site, Aiken, SC

Liu, E. H., R. R. Sharitz, and M. H. Smith, 1978. "Thermal Sensitivities of Malate Dehydroganase Isozymes in Typha". American Journal of Botany, 65(2):214:220.

Merandino, M. T. and L. M. Smith. 1991. "Influence of Draw down Date and Reflood Depth on Wetland Vegetation Establishment." Widl. Soc. Bull. 19:143-150.

Millar, J. B. 1973. "Vegetation Changes in Shallow Marsh Wetlands Under improving Moisture Regime." Can. J. Bot. 51:1443-1457.

Mueller-Dombois, D., and H. Ellenberg. 1974. Aims and Methods of Vegetation Ecology. John Wiley \& Sons, Inc. NY, NY 547pp.

Narumalani, S. 1993. Classification and Modeling of Aquatic Macrophytes Using Remote Sensing and Geographic Information Systems. Dissertation, Department of Geography, University of South Carolina, Columbia, SC 29208 pp. 105.

Phillips, E. A. 1959. Methods of Vegetation Study. Holt, Rinehart and Winston, Inc., NY, NY $107 \mathrm{pp}$.

Wilde, E. W. and L. J. Tilly. 1985. Influence of P-Reactor Operation on the Aquatic Ecology of Par Pond-A Literature Review. DP-1698, E. I. du Pont de Nemours and Company, Savannah River Laboratory, Aiken, SC 29808 